\title{
Agnès Rees, Poétiques de la «vive représentation» de Marco Girolamo Vida (1527) à Jacques Peletier du Mans (1555)
}

\section{Dario Cecchetti}

\section{(2) OpenEdition}

\section{Journals}

\section{Edizione digitale}

URL: http://journals.openedition.org/studifrancesi/6585

DOI: $10.4000 /$ studifrancesi.6585

ISSN: 2421-5856

\section{Editore}

Rosenberg \& Sellier

\section{Edizione cartacea}

Data di pubblicazione: 1 septembre 2010

Paginazione: 350

ISSN: 0039-2944

\section{Notizia bibliografica digitale}

Dario Cecchetti, «Agnès Rees, Poétiques de la «vive représentation» de Marco Girolamo Vida (1527) à Jacques Peletier du Mans (1555)», Studi Francesi [Online], 161 (LIV | II) | 2010, online dal 30 novembre 2015, consultato il 12 janvier 2021. URL: http://journals.openedition.org/studifrancesi/6585; DOI: https://doi.org/10.4000/studifrancesi.6585

Questo documento è stato generato automaticamente il 12 janvier 2021.

\section{cc) $($ ) $\ominus$}

Studi Francesi è distribuita con Licenza Creative Commons Attribuzione - Non commerciale - Non opere derivate 4.0 Internazionale. 


\title{
Agnès Rees, Poétiques de la «vive représentation» de Marco Girolamo Vida (1527) à Jacques Peletier du Mans (1555)
}

\author{
Dario Cecchetti
}

\section{NOTIZIA}

AGNÈS REES, Poétiques de la «vive représentation» de Marco Girolamo Vida (1527) à Jacques Peletier du Mans (1555), «Italique», XII (2009), pp. 93-122.

1 La nozione di vive représentation, che ricorre nei testi teorici francesi del Rinascimento, è ripresa spesso dalla critica moderna per indicare una certa pratica della descrizione nella poesia del Cinquecento. Agnès Rees si propone di definire con precisione questa nozione, sempre connessa a un ideale di claritas, di perspicuitas e di vivacità. I termini cronologici dell'indagine vanno dal De arte poetica di Marco Girolamo Vida (1527) all'Art poétique di Jacques Peletier du Mans (1555) passando per il trattato in versi Dell'arte poetica di Girolamo Muzio (1551), arco di tempo in cui la cosiddetta poetica della vive représentation viene formulata nelle discussioni prima italiane e poi francesi, per sfociare in una definizione della «représentation la plus prochaine entre les choses et les mots» (Peletier, I, 9). Sono gli elementi di questa definizione e le finalità teoriche della vive représentation a venire ripercorsi e studiati dall'A., in particolare nel testo di Peletier, con puntuali raffronti alle altre due arti poetiche citate. 